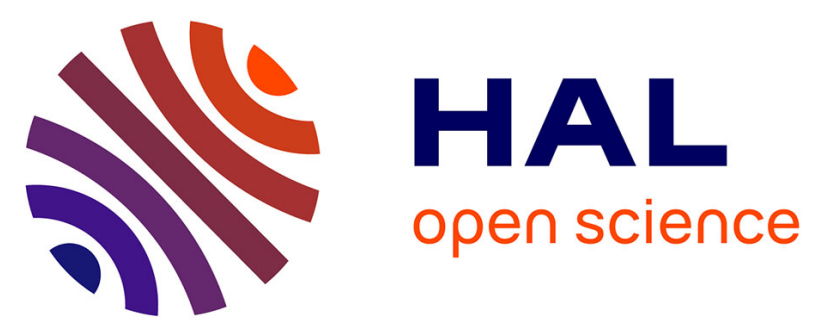

\title{
Laparoscopic Management of an Intrauterine Fallopian Tube Incarceration After Curettage for a Non-progressing Pregnancy
}

Margaux F. Camus, Pauline Chauvet, Constance Hordonneau, Anne-Laure Lafaye, Michel Canis, Nicolas Bourdel

\section{To cite this version:}

Margaux F. Camus, Pauline Chauvet, Constance Hordonneau, Anne-Laure Lafaye, Michel Canis, et al.. Laparoscopic Management of an Intrauterine Fallopian Tube Incarceration After Curettage for a Non-progressing Pregnancy. Journal of Minimally Invasive Gynecology, 2019, 26, pp.805 -. 10.1016/j.jmig.2018.09.770 . hal-03484927

\section{HAL Id: hal-03484927 \\ https://hal.science/hal-03484927}

Submitted on 20 Dec 2021

HAL is a multi-disciplinary open access archive for the deposit and dissemination of scientific research documents, whether they are published or not. The documents may come from teaching and research institutions in France or abroad, or from public or private research centers.
L'archive ouverte pluridisciplinaire HAL, est destinée au dépôt et à la diffusion de documents scientifiques de niveau recherche, publiés ou non, émanant des établissements d'enseignement et de recherche français ou étrangers, des laboratoires publics ou privés.

\section{(ㅇ)(1) $\$$}

Distributed under a Creative Commons Attribution - NonCommerciall 4.0 International 
1. Title: Laparoscopic management of an intrauterine fallopian tube incarceration after curettage for a non- progressing pregnancy.

2. Authors names and affiliation

3. Margaux F. CAMUS, M.D'1 , Pauline CHAUVET, M.D ${ }^{1}$, Constance HORDONNEAU, M.D², Anne-Laure LAFAYE, M.D³ , Michel CANIS, M.D, Ph.D', Nicolas BOURDEL, M.D, Ph.D ${ }^{1}$

4. ${ }^{1}$ Department of Gynecologic Surgery, University Hospital Estaing, ClermontFerrand, France.

5. ${ }^{2}$ Radiology department, University Hospital Estaing, Clermont-Ferrand, France

6. ${ }^{3}$ Anestesiology department, University Hospital Estaing, Clermont-Ferrand, France.

7. Corresponding author : Margaux Camus : marg.camus@gmail.com

8. +3376934 4684 Department of Gynecologic Surgery, University Hospital Estaing, Clermont-Ferrand, France.

9. Declarations of interest: The authors declare that they have no conflicts of interest and nothing to disclose. 


\section{Abstract}

2. Study Objective:_To report a case of a laparoscopic repair of an intrauterine fallopian tube incarceration as complication of curettage

3. Design: A step-by-step explanation of the surgery using video (instructive video), approved the local Institutional Review Board (Canadian Task Force III)

4. Setting: University Hospital Estaing, Clermont-Ferrand, France

5. Patient: A 29-year-old woman experiencing a non evolving pregnancy at 8 weeks underwent a curettage. After nine months, she complained from abnormal vaginal discharge. Ultrasound evaluation showed a right parauterine mass. She reported a maternal medical history of ovarian cancer in a context of Lynch syndrome. A MRI described a right hydrosalpinx of $12 \mathrm{~mm}$ diameter, with a suspect fimbriae lesion of the tuba and a $7 \mathrm{~mm}$ endometriosis nodule of the uterine torus.

6. Intervention: We decided to explore the tuba by laparoscopy and to perform an hysteroscopy. A fallopian tube incarceration was suspected during hysteroscopy: a defect of the uterine wall was observed, through which there was protrusion of a tubal fimbriae. The laparoscopic view of the pelvis confirmed the incarceration of the right fallopian tube through the uterine wall. It was carefully extracted out of the uterine defect. The uterine wall defect was repaired with an X point with Monocryl 1. 
7. Measurements and main results: A tubal patency test was performed, which was positive on both sides. As phimosis responsible for the hydrosalpinx had been treated, salpingectomy was not performed.

8. Conclusion: Curettage for miscarriage or undesired pregnancy is not exempt from complications (as hemorrhage, simple perforation, or infection) Intrauterine fallopian tube incarceration is uncommon but can affect fertility. This diagnosis is important to avoid destruction of the fimbriae, necrosis of the tube and also to reduce the risk for ectopic pregnancy. 
